\title{
Use of minute duckweed (Lemna perpusilla) for supplemental feed in catfish (Clarias sp.) culture: determination of the optimal proportion using powersim simulation
}

\author{
Tjandra Chrismadha ${ }^{1, *}$, Livia Rossila Tanjung ${ }^{1}$, Sutrisno ${ }^{1}$ \\ ${ }^{1}$ Research Center for Limnology, National Research and Innovation Agency (BRIN), Cibinong, \\ Indonesia
}

\begin{abstract}
Catfish farming is very profitable because the fish is easy to rear and can be harvested quickly. However, the cost of feed as the most significant component in production costs is currently getting higher. The availability and utilization of alternative feed is an urgent solution in creating sustainable catfish farming. This research was carried out during December 2020 - January 2021 in the Research Center for Limnology, Cibinong, Indonesia, which aims to determine the optimal proportion of minute duckweed (Lemna perpusilla) biomass added as feed supplemental to obtain an optimum growth of catfish fingerlings (Clarias sp.). Catfish were reared for 63 days in nine aquariums with a density of 25 fish per aquarium. The commercial pellet given in the control aquarium was $100 \%$ pellet portion ( $5 \%$ of the total fish weight), while in the treatment aquariums were $60 \%$ and $40 \%$ of the total fish weight. As compensation, fresh duckweed ( $L$. perpusilla) was provided ad libitum. Fish were sampled twice to measure their weight and body length. This study showed that the proportion of duckweed as much as $40 \%$ as a supplement for commercial pellets could produce optimal catfish growth.
\end{abstract}

\section{Introduction}

Aquaculture of catfish (Clarias sp.) is increasingly popular because they grow faster than other fish species, in addition to requiring less water. However, to support the rapid growth of catfish, more feed is needed, which is currently a significant constraint in aquaculture as the price continues to rise [1]. Therefore, there is an urgent need to seek alternative feeds, particularly cheap protein sources, to promote sustainable and environmentally friendly catfish farming.

The plant-based feed has been pointed out as one of the feasible alternatives to increase the availability of protein sources. There has also been emphasized some nutritional requirements and biomass availability to select the right plant for alternative feeds [2-6]. The nutritional requirement includes high protein content, favorable amino acid profile, high

\footnotetext{
*Corresponding author : tjandra@limnologi.lipi.go.id
} 
nutrient digestibility, and reasonable palatability, while low levels of fiber, starch, especially non-soluble carbohydrates and antinutrients [7]. At the same time, biomass availability is mainly determined by the capacity of plant productivity in each available land throughout the seasons.

One of these potential plants is minute duckweed (Lemna perpusilla Torrey) which grows cosmopolitan in tropical freshwaters [8]. It is a small floating spermatophyte on the water surface, one of 14 species belonging to the genera of Lemna, which is taxonomically grouped into the family of Lemnaceae [9]. Minute duckweed and the other members of Lemnaceae have been pointed out to have great potential as alternative feeds due to their high growth rate and biomass productivity $[10,11]$, along with the advantage of high nutrition value, particularly the high protein content with complete amino acids composition [10-15].

The duckweed plant can be produced inexpensively by using animal wastes as nutrient sources or integrating plant cultivation into a wastewater treatment system [12, 14, 15, 16,]. Reports confirmed that minute duckweed (L. perpusilla) grew well in aquaculture wastewater media $[14,17]$, converting this waste into valuable biomass for alternative feed. Thus, minute duckweed will provide double advantages, which are resources for alternative diet while reducing waste in the water $[14,18]$.

Some studies on duckweed as an alternative feed for various animals have been carried out, including ducks, pigs, cows, and fish [12]. Several fish species, in particular, have been shown to respond well to the duckweed diet, including nile tilapia [17, 19, 20], grass carp [21], and common carp [22]. No study, however, has been reported to elaborate on the potential of minute duckweed as an alternative feed in catfish farming. In contrast, field observation showed that the fish consumes available minute duckweed which possibly serves as the other diet. Accordingly, catfish that were once thought to be carnivorous fish are omnivores. It is consistent with Tesfahun [23], who reported a natural feeding behavior of African catfish (C. gariepinus) that consumes macrophytes among other available feed sources in an Ethiopian lake. This study aims to further elaborate on the potential use of minute duckweed for supplemental feed in catfish (Clarias sp.) culture and determine the optimal amount of fresh duckweed (L. perpusilla) biomass to reduce commercial pellets application to develop a more efficient and environmentally friendly catfish farming.

A growth model describes mass deposition in an organism based on nutrient inputs [24]. An explanatory model for the growth of juvenile African catfish has been developed and tested by Machiels and colleagues [25, 26, 27]. This model can predict development and changes in body composition with time under different feeding levels and feed compositions. This study simulates the growth based on the specific growth rate (SGR) as the most determining parameter for the bodyweight, using Powersim Studio 10 Express. Powersim has been used in various fields of study, such as electronics and informatics [28, 29], forestry [30], the fast-food industry [31], medicine [32], and waste management [33]. In aquaculture, Powersim should also be used to plan production targets and evaluate the growth performance of the cultured fish. In this study, a growth simulation model was performed to describe a more realistic fish response to various levels of commercial feed supplement.

\section{Materials and methods}

\subsection{Experimental plant and fish}

Minute duckweed (L. perpusilla) was grown in ponds enriched with nutrients from the wastes of catfish culture. It was among the collection of aquatic plants in the Research Center for Limnology, Indonesian Institute of Sciences (LIPI), which was initially taken from waters 
near Bogor Regency. The catfish (Clarias sp.) fingerlings used in this study were obtained from the culture in the RC for Limnology LIPI.

\subsection{Culture system}

A recirculating aquaculture system was used to carry out the experiment (Figure 1), consisting of nine glass aquaria (1), each measuring $0.6 \times 0.4 \times 0.4 \mathrm{~m}^{3}$ arranged in a U shape. Water from the fiberglass reservoir (8) measuring $2.0 \times 1.0 \times 0.5 \mathrm{~m}^{3}$ was pumped by a centrifugal pump (9) (Sanyo 3,000 L/hour) through the PVC distribution pipe (3) and flowed equally into each aquarium (2). Water exits the aquarium through a drain at the bottom of each aquarium (4), then flows by gravity through a 2-inch PVC drainage pipe (5) into a 1.0 $\times 0.6 \times 0.6 \mathrm{~m}^{3}$ fiberglass sedimentation tank (6). The water flows by gravity from the sedimentation tank through a 2-inch PVC U-pipe system (7) to the fiberglass reservoir (8).

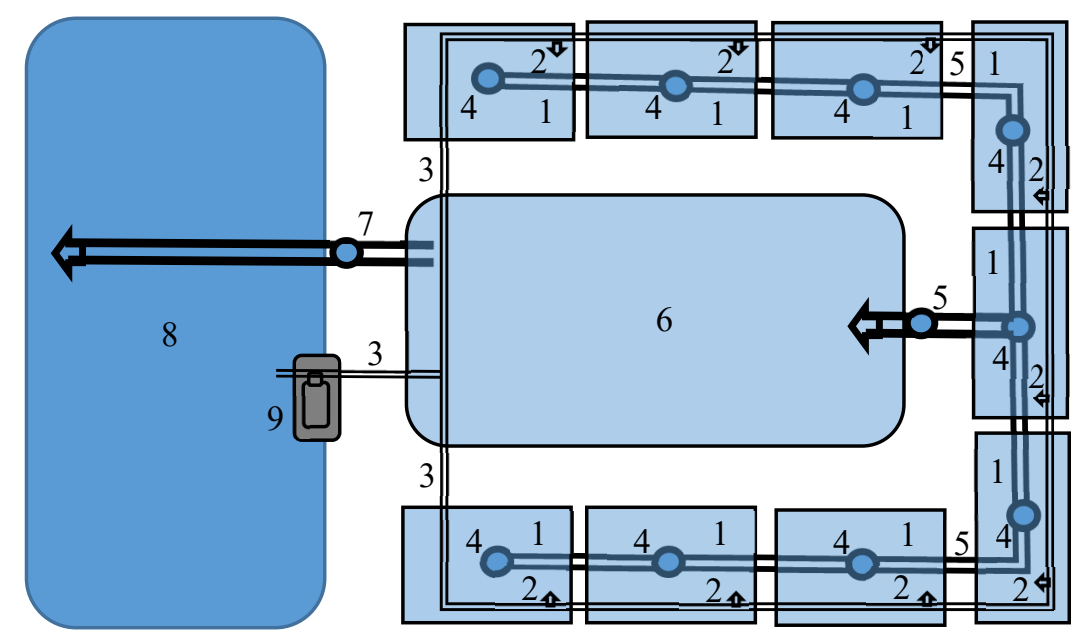

Fig. 1. Arrangement of culture system: nine glass aquaria (1), water drop flow (2), distribution pipe (3), drain at the bottom of aquarium (4), drainage pipe (5), sedimentation tank (6), U-pipe system (7), reservoir (8).

\subsection{Experiment}

The experiment was carried out during December 2020 - January 2021 in the greenhouse of the Research Center for Limnology, Indonesian Institute of Sciences, Cibinong, Indonesia, at room temperature of $27.4-34.3^{\circ} \mathrm{C}$. Catfish fingerlings were stocked into the aquariums with a density of 25 fish per aquarium $\left(100 \mathrm{fish} / \mathrm{m}^{2}\right)$. The average size of the fish was 11.89 $\pm 2.60 \mathrm{~g} /$ fish. The catfish were reared for 63 days. The commercial pellet given in the control aquarium was $5 \%$ of the total fish weight (100\% pellet portion). Commercial fish pellets (HiPro-Vite 781-1), which is claimed to contain $31-33 \%$ protein, $4-6 \%$ fat, $3-5 \%$ fiber, were given as the main diet and were provided in various portions based on the commonly recommended feed rations ( $5 \%$ of total fish weight), that is $100 \%$ as control, $60 \%$, and $40 \%$. Predetermined-weight commercial pellets as feed were given each morning. As compensation for the reduced chow, ad libitum fresh duckweed biomass was delivered and added every morning and evening when exhausted. It was taken directly from nearby ponds and was given based on the assumption that pellets-lacking fish will eat more duckweed as 
supplemental feed. The fresh biomass was swayed to minimize moisture content, then weighed before being fed to the fish.

The water quality during the study was maintained at a water conductivity below 500 $\mathrm{mS} / \mathrm{cm}$, measured with conductivity meter Lutron YK-200PCT (Taiwan). When it exceeded this value, about $1 / 3$ of the water was replaced, which was done twice towards the end of the study.

\subsection{Growth and productivity observation}

Fish growth was measured using parameters of fish body length, measured on a fishing ruler at $1 \mathrm{~mm}$ values, and weight using a weight scale at $0,01 \mathrm{~g}$ values. The fish were sampled twice: on day-28 and day-63.

\subsection{Data analysis}

The performance of catfish production that includes the specific growth rate, the weight gain, the condition factor, the survival rate, the total amount of feed consumed, and the feed conversion ratio were analyzed at the end of the study. These parameters were evaluated statistically employing one-way ANOVA at a 95\% confidential rate, followed by an LSD test using Microsoft Excel.

The specific growth rate (SGR) expressed in \%/day is calculated using the formula [34]:

$$
S G R=\frac{\ln W t-\ln W o}{T} \times 100
$$

The average daily growth (ADG) is the weight gained by the fish per day:

$$
A D G=\frac{W t-W o}{T}
$$

Where Wt and Wo are the final, initial average weights $(\mathrm{g})$ of fish and $\mathrm{T}$ is the time interval (days).

The condition factor $(\mathrm{g} / \mathrm{cm})$ is the ratio between the weight and length of the fish:

$$
C F=\frac{\text { Weight }}{\text { Length }}
$$

The survival rate (SR) expressed in \% is calculated using the formula:

$$
S R=\frac{N t}{N o} \times 100
$$

Where Nt and No are the final and initial numbers of fish.

The total amount of feed consumed (TF) expressed in $\mathrm{g}$ is calculated using the formula:

$$
T F=T P+T D
$$

Where TP is total pellets (g), and TD is total duckweed dry weight (g).

The dry weight of minute duckweed biomass was determined by taking a sample of $6 \times$ $50 \mathrm{~g}$ and heating it in an oven at $60^{\circ} \mathrm{C}$ for 24 hours. The average water content obtained was then used to convert the fresh plant biomass to dry weight. 
The feed conversion ratio (FCR) is calculated using the formula:

$$
F C R=\frac{T F}{T W}
$$

where TF is total feed consumed (g), and TW is the final weight of fish (g).

\subsection{Final weight simulation}

The scenario of this study was developed based on the SGR values obtained in this experiment to achieve the final weight of each fish of $125 \mathrm{~g}$, which is the most preferred size for making a popular local food menu called Pecel Lele. The final weight of catfish was simulated using Powersim Studio 10 Express, which gives the ability to build simulation models and run simulation scenarios with basic modeling features. The scenario results were then used to evaluate the culture performance and determine the optimal duckweed supplementation.

\subsection{Model validation}

The model was validated by comparing the simulation result to the research data using the Barlas model to determine the suitability of the simulation with the actual data by dividing the absolute error value in each period by the true value. The accuracy criteria of the model are exact if the percentage of error in the means (E1) or the rate of error in the variations (E2) is less than $5 \%$, correct if it is in the range of $5-10 \%$, and less precise if it is more than $10 \%$ [35].

$$
\begin{aligned}
& E 1=\frac{|\overline{\mathrm{S}}-\overline{\mathrm{A}}|}{\overline{\mathrm{A}}} \times 100 \\
& E 2=\frac{\left|\mathrm{S}_{\mathrm{S}}-\mathrm{S}_{\mathrm{A}}\right|}{\mathrm{S}_{\mathrm{A}}} \times 100
\end{aligned}
$$

\section{Results}

\subsection{Duckweed consumption}

Catfish consume well fresh biomass of duckweed. Higher consumption of duckweed was observed with smaller pellet portions. As shown in Figure 2, duckweed biomass consumption was only $5.3 \%$ of the total feed when the pellet portion was given $100 \%$, and it increased to $10.3 \%$ and $21.9 \%$ when the pellet portion was reduced to $60 \%$ and $40 \%$, respectively. However, the total feed consumption in combination decreased with the reduction of pellet portion, which were $3,435.75 \mathrm{~g}, 2,130.59 \mathrm{~g}$, and $1,241.33 \mathrm{~g}$ at the pellet portion of 100,60 , and $40 \%$, respectively. 


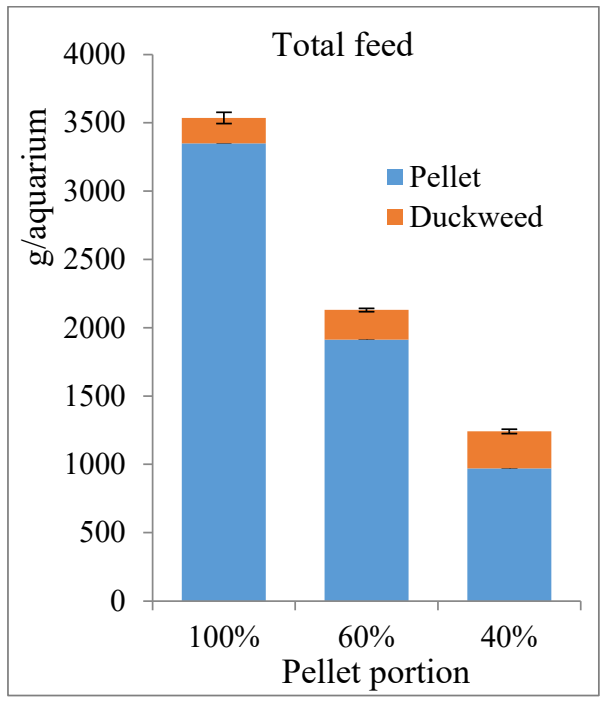

(a)

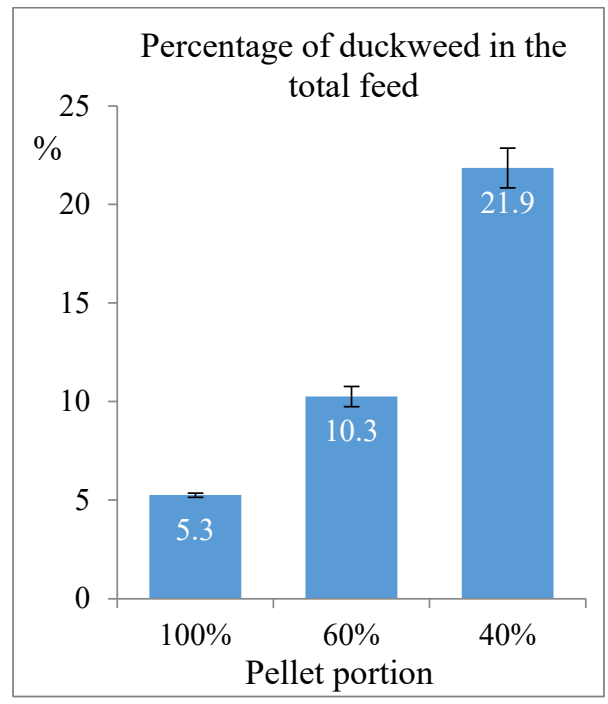

(b)

Fig. 2. The total feed is given (a) and the percentage of duckweed in the total feed (b).

\subsection{Catfish culture performance}

A remarkable impact of pellet reduction was observed on the growth performance of catfish, except survival rates. The $100 \%$ pellet portion resulted in the highest specific growth rate (SGR) of catfish with an average of $3.6 \pm 0.3 \%$ per day, an average daily growth (ADG) of $1.6 \pm 0.15 \mathrm{~g} / \mathrm{fish}$, and condition factor $(\mathrm{CF})$ of $4.5 \pm 0.45 \mathrm{~g} / \mathrm{cm}$. The SGR, ADG, and CF consistently decreased with pellet reduction to $3.3 \pm 0.3 \%$ per day, $1.3 \pm 0.2 \mathrm{~g} /$ fish, and 3.8 $\pm 0.4 \mathrm{~g} / \mathrm{cm}$ at $60 \%$ pellet portion, and $2.6 \pm 0.3 \%$ per day, $0.8 \pm 0.1 \mathrm{~g} / \mathrm{fish}$, and $2.8 \mathrm{~g} / \mathrm{cm}$ at $40 \%$ pellet portion, respectively (Figure 3 ).

The fish condition factor (CF) value of 4.54 at $100 \%$ pellet portion indicated excellent and healthy fish conditions. Although the $\mathrm{CF}$ average value at $60 \%$ pellet portion was lower than at $100 \%$ pellet portion, the statistic test showed no remarkable difference between the fish given $100 \%$ and $60 \%$ pellet portions. The CF value was primarily correlated with fish development. So, although lower CF values were observed with pellet reduction in this study, this did not necessarily become a significant concern, as the appropriate value would be reached when the fish entered the target size. 


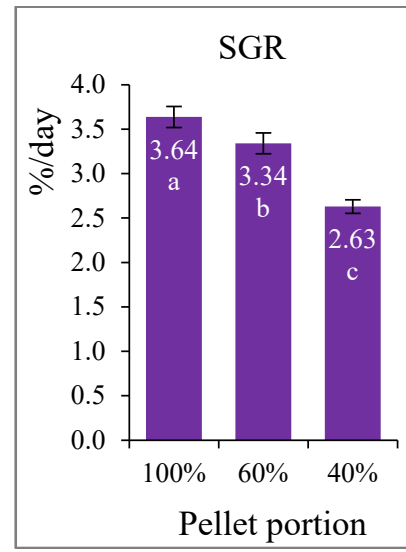

(a)

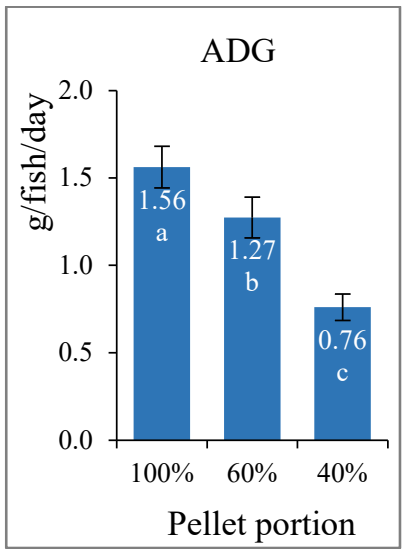

(b)

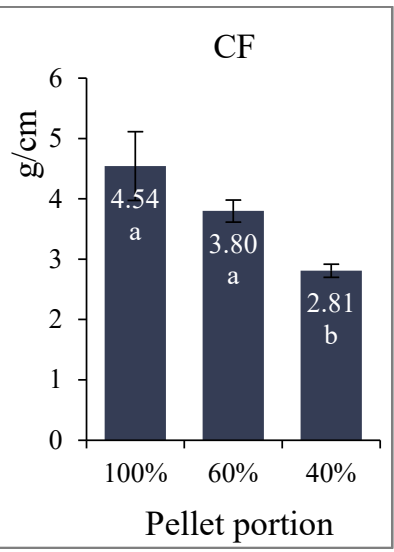

(c)

Fig. 3. The values of SGR (a), ADG (b), and CF (c) of catfish during the study; different letters below the given values indicated significant difference at $95 \%$ confidential rate.

The survival rate values (SR) showed no remarkable effect of pellet reduction supplemented by minute duckweed was observed in the survival rate values (SR), which ranged 92-98\%. A slightly higher SR was honored at the lowest pellet portion (Figure 4). The FCR values, which are consistently lower with decreasing pellet portions, were also shown in Figure 4.

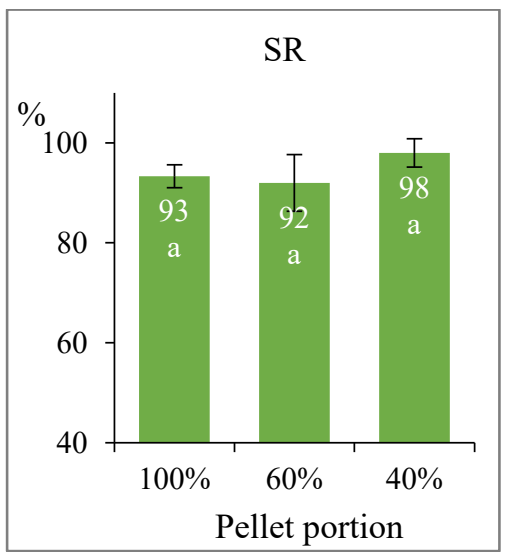

(a)

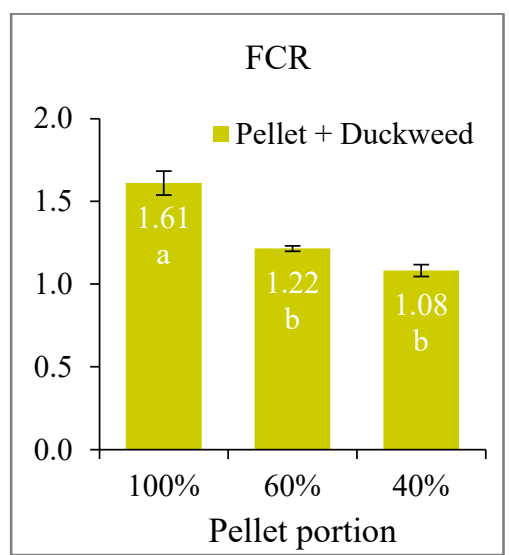

(b)

Fig. 4. Survival rates (SR, a) and feed conversion ratio (FCR, b) of catfish during the study; different letters below the given values indicated significant difference at $95 \%$ confidential rate.

\subsection{Supplemental feed simulation}

The growth pattern of catfish up to day- 63 showed an exponential mode with all $\mathrm{R}^{2}$ values greater than 0.99 , while a consistent lower gradient was observed concurred with the SGR values as the consequence of pellet reduction. This significantly impacted the final fish weight on day-63, 105.7, 88.4, and 57.6 g/fish for the treatments with 100,60 , and $40 \%$ pellet portions (PP), respectively (Figure 5). In the meantime, the growth simulation using Powersim Studio 10 Express resulted in the final fish weight of 104.8, 88.3, and $58.6 \mathrm{~g} / \mathrm{fish}$ 
on day-63 for the SGR values of 3.6, 3.3, and 2.6\%/day, respectively (Figure 6). Model validation using the Barlas equation showed that the SGR-based simulation is exact because the E1 and E2 values are $0.87 \%$ and $4.84 \%(<5 \%)$.

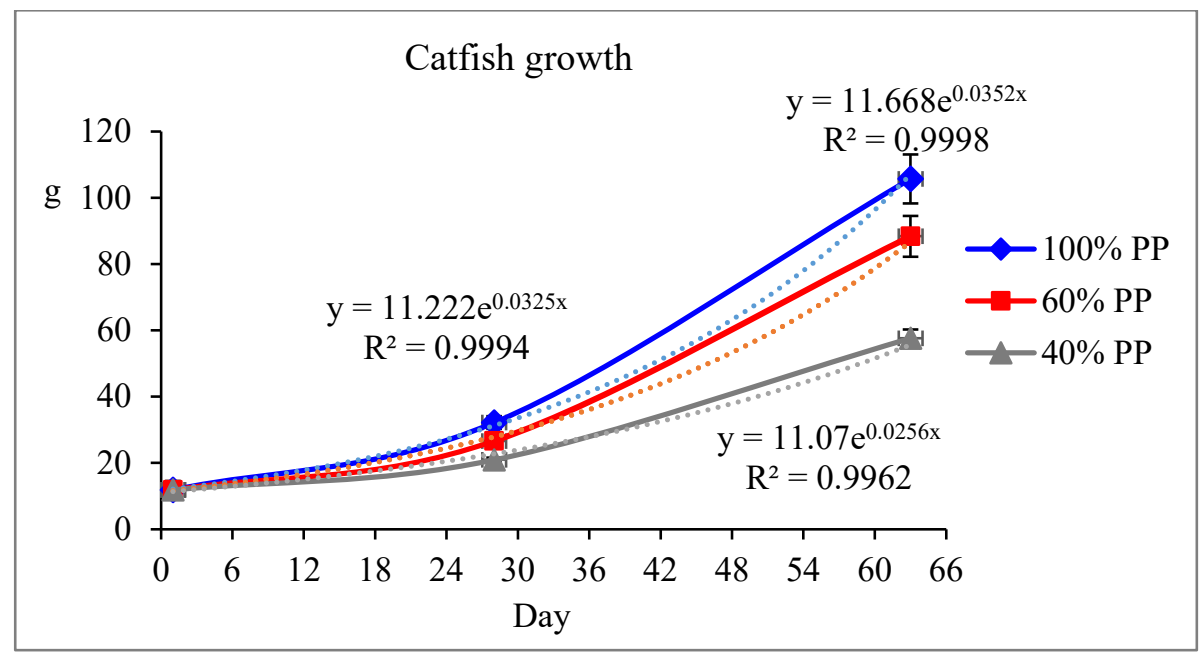

Fig. 5. Growth of catfish during the study.

The further simulation revealed that pellet reduction impacted the cultivation time to achieve any target size of fish. For example, at a target size of $125 \mathrm{~g} /$ fish, the time required for cultivation was 68 days at $100 \%$ pellet portion (Figure 6, blue arrow), while at $60 \%$ and $40 \%$ pellet portions were 74 days and 93 days, respectively (Figure 6, red and green arrows). Consequently, as shown in Table 1, pellet reduction resulted in remarkably lower productivity loads in fish biomass and economic value, which accounted for up to $9.4 \%$ at $60 \%$ pellet portion and $23.2 \%$ at $40 \%$ pellet portion.

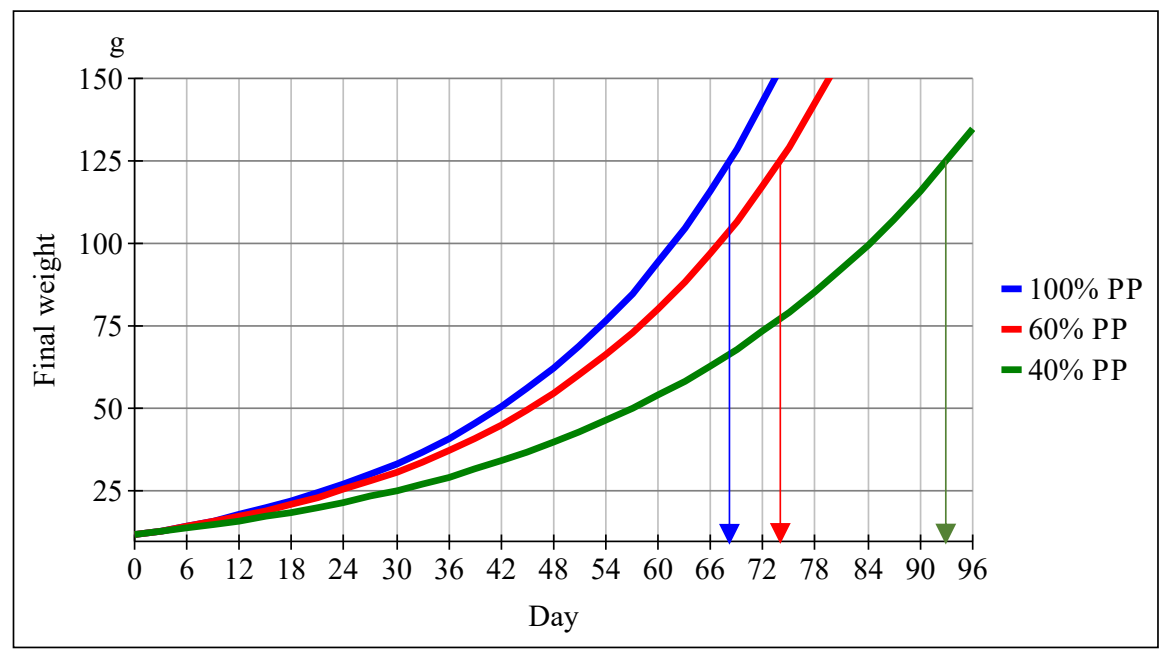

Fig. 6. Harvest time simulation using Powersim to obtain a $125 \mathrm{~g}$ fish weight target. 
Table 1. Simulation of productivity load according to the three pellet portions.

\begin{tabular}{|c|c|c|c|c|c|c|}
\hline Pellet portion & SR & \multicolumn{2}{|c|}{ Fish final weight } & $\begin{array}{c}\text { Culture } \\
\text { duration* }\end{array}$ & \multicolumn{2}{c|}{ Productivity load } \\
\hline$\%$ & $\%$ & $\mathrm{~g} /$ fish & $\mathrm{g} /$ aquarium & days & $\mathrm{g} / \mathrm{m}^{2} / \mathrm{day}$ & $\mathrm{IDR} / \mathrm{m}^{2} / \mathrm{day}^{* *}$ \\
\hline 100 & 93.3 & 125 & $2,915.6$ & 68 & 171.5 & 4,288 \\
\hline 60 & 92.0 & 125 & $2,875.0$ & 74 & 155.4 & 3,885 \\
\hline 40 & 98.0 & 125 & $3,062.5$ & 93 & 131.7 & 3,293 \\
\hline
\end{tabular}

Note: * To obtain a fish size of $125 \mathrm{~g} . * *$ fish price is IDR25,000/kg

On the other hand, this study also demonstrated that reducing pellet portion coupled with supplementation of minute duckweed could lead to a more efficient culture in terms of feed expenditure. This feature was revealed from the simulation of feed requirements according to the FCR values obtained from this experiment (Figure 4), in which the result is summarized in Table 2. The addition of duckweed as a supplemental pellet can reduce the feed cost by up to $26.4 \%$ at $60 \%$ pellet and $38.8 \%$ at $40 \%$ pellet portions.

Table 2. The total cost of catfish feed based on the supplemental feed simulation.

\begin{tabular}{|c|c|c|c|c|c|c|c|c|c|}
\hline \multirow{3}{*}{$\begin{array}{c}\text { Pellet } \\
\text { portion }\end{array}$} & \multirow{5}{*}{ FCR } & \multicolumn{8}{|c|}{ Feed } \\
\hline & & \multicolumn{5}{|c|}{ Composition } & \multicolumn{3}{|c|}{ Cost } \\
\hline & & \multicolumn{2}{|c|}{ Pellet } & \multicolumn{3}{|c|}{ Duckweed } & \multirow{3}{*}{$\begin{array}{c}\text { Pellet* } \\
\text { IDR }\end{array}$} & \multirow{3}{*}{$\begin{array}{c}\text { Duckweed }^{* *} \\
\text { IDR }\end{array}$} & \multirow{3}{*}{$\begin{array}{l}\text { Total } \\
\text { IDR }\end{array}$} \\
\hline \multirow{2}{*}{$\%$} & & \multirow{2}{*}{$\%$} & \multirow{2}{*}{$\mathrm{kg}$} & \multirow{2}{*}{$\%$} & \multicolumn{2}{|c|}{$\mathrm{kg}$} & & & \\
\hline & & & & & Dry & Fresh & & & \\
\hline 100 & 1.61 & 94.70 & 1.53 & 5.30 & 0.09 & 1.42 & 15,295 & 427 & 15,722 \\
\hline 60 & 1.22 & 89.70 & 1.09 & 10.30 & 0.13 & 2.09 & 10,943 & 628 & 11,572 \\
\hline 40 & 1.08 & 78.10 & 0.84 & 21.90 & 0.24 & 3.94 & 8,435 & 1,183 & 9,617 \\
\hline
\end{tabular}

Note: * Pellet price is IDR10,000 per kg. ** Duckweed price is IDR300 per kg.

\section{Discussion}

This study showed that catfish consume well fresh biomass of duckweed. Even at the proper portion of pellets, catfish consumed a remarkable amount of duckweed, and the consumption rate increased with smaller pellet portions. The ability of catfish to digest plant materials such as minute duckweed is not very surprising, as familiar fish feed formula consists of certain plant materials, such as soybeans, rice bran, and corn powder. Musiba et al. [36] reported better catfish growth performance obtained by replacing all fishmeal with soybeans. Tesfahun [23] also observed macrophyte material as part of the natural diet consumed by African catfish in their natural lake and considered it unintentional ingestion. This study shows that catfish can use macrophyte material, particularly minute duckweed, to meet nutritional needs in limited feed conditions, so plant biomass can be considered a high potential alternative feed. This phenomenon is very interesting given that the current major obstacle in fish farming is obtaining cheap sources of protein to prepare economically viable feed ingredients [1]. As reported by Chrismadha and Said [37], minute duckweed can be produced year-round in the tropics based on a low-cost integrated farming system that uses catfish waste as a source of nutrients, where the selling price of the product is IDR300 per kg with comparable business margins or even higher than conventional rice-growing activities. 
At the same time, lower feed consumption at common pellet portions was revealed when minute duckweed was expressed in dry biomass. In contrast, comparable consumption weight was obtained in fresh biomass-based observations, which might be attributed to the nature of fresh duckweed biomass with the water content of about $94 \%$ and makes it more voluminous for fish consumption. This means that duckweed consumption was limited by volume, which may be related to fish digestibility.

The reduction of the pellet portion is very influential on the growth performance of the catfish. This phenomenon might be attributed to a better nutrition value of pellets as it has been developed to complete all the fish growth requirements. Even though the duckweed biomass has been reported to have a higher protein content with complete amino acids composition [15], the overall nutrient composition is likely less suitable for catfish, which naturally tend to be carnivorous.

The SGR value achieved in this study is comparable to Hariyadi et al. [38], which reported the range of catfish growth rate of $2-4 \%$ /day feeding on commercial pellets in almost the same size containers and culture densities. Other studies reported lower SGR values, such as Musefiu [39] and Soedibya et al. [40]. A remarkably lower growth rate of the fish was obtained by Amisah et al. [41] when reducing fish meal and substituted it with Leucaena leaf in the feed ingredient. The lower growth rate with feed reduction has also been reported, in which about $58 \%$ growth decrease occurred when pellet delivery decreased from $5 \%$ to $2 \%$ of fish body weight [42].

Remarkably more minor growth rate retardation observed in this study, only $23.2 \%$ when the pellets were reduced from $5 \%$ to $2 \%$ of the total body weight, could be attributed to the provision of additional minute duckweed. It emphasizes the definite role of minute duckweed as a suitable supplemental feed that can be applied to reduce the need for commercial pellets in catfish aquaculture. Consistent with the results of this study, Marimuthu et al. [42] also showed lower catfish weight gain with less amount of feed. Parameters of weight gain are naturally a function of body weight and growth rate. So, in every homogeneous culture, the ADG value is closely related to the SGR and will show a similar pattern of values at any definite time. Both SGR and ADG can be used to estimate the time required for the culture to reach a specific target size of fish.

The highest SR value, shown in Figure 4, at the lowest pellet portion observed in this study was consistent with Marimuthu et al. [42]. They also reported a trend for a higher SR value with a lower diet. They associated it with the behavior of cannibalism, which increasingly occurred under the availability of luxurious foods. A lower FCR value (Figure 4) indicated a more efficient metabolism of food into fish biomass. This means that in case of insufficient pellet supply, duckweed can be served as an excellent supplementary feed to enhance a more efficient catfish production. It is suggested that a more efficient culture can be developed by determining the optimal pellet reduction, which stimulates the fish to feed on duckweed as much as possible while ensuring proper growth. This study shows that the pellet portion of $60 \%$ is the most reasonable pellet reduction, which can be optimally substituted by duckweed biomass provision, as it only reduces the ADG by $18.59 \%$, while it gives an impact on a significant production cost efficiency.

The optimal proportion of pellet reduction and involvement of minute duckweed is suggested to be elaborated to take maximum advantage of the use of this aquatic plant. This suggestion is supported by the simulation model using Powersim Studio 10 Express, which gives further guidance to achieve optimal use of minute duckweed for catfish production based on the fish size target product (Figure 6). It is pointed out that reducing pellet portion coupled with supplementation of minute duckweed can lead to a more efficient culture in terms of feed expenditure. Still, it prolongs the culture time and potentially reduces land productivity. Consequently, the effort to obtain advantages of using minute duckweed as supplemental feed in catfish culture has also to consider other production factors, particularly 
culture duration and land value. The application would become a more robust option under conditions of less pellet availability and lower land value. It is recommended that the implementation of minute duckweed to reduce commercial pellet requirement in catfish culture is directed to overcome operational constraints due to the high price of pellets, particularly in small businesses with limited working capital.

\section{Conclusion}

Minute duckweed supplementation could be applied to compensate for pellet reduction in catfish culture. Pellet reduction up to $40 \%$ is considered as the optimal application, in which up to $26.4 \%$ feed efficiency can be obtained while the fish production rate only decreases by $18.59 \%$, which gives an acceptable extend of culture duration.

\section{Acknowledgment}

This research was supported by the Research Center for Limnology - Indonesian Institute of Sciences (LIPI) Financial Budget 2020. Thanks to Dr. Nofdianto for permission to use the experimental culture unit and Zaenal for helping in catfish fingerling preparation and experiment maintenance.

\section{References}

1. G. Kumar and C. R. Engle, Aquac. Econ. Manag., 18, 2 (2014)

2. M. Espe, A. Lemme, A. Petri, and A. El-Mowafi, Aquaculture, 263, 1-4 (2007)

3. A. C. Hansen, G. I. Hemre, Karlsen, W. Koppe, G. Rosenlund, Aquac. Nutr., 17, 2 (2011)

4. C. Nasopoulou and I. Zabetakis, LWT - Food Sci. Technol., 47, 2 (2012)

5. Z. Sankian, S. Khosravi, Y. O. Kim, S. M. Lee, Fish. Aquat. Sci., 22, 1 (2019)

6. L. M. P. Valente, E. M. Cabral, V. Sousa, L. M. Cunha, J. M. O. Fernandes, Aquaculture, 453 (2016)

7. D. M. Gatlin et al., Aquac. Res., 38, 6 (2007)

8. J. V. Pancho and M. Soerjani, Aquatic weeds of Southeast Asia. A systematic account of common Southeast Asian aquatic weeds (BIOTROP, SEAMEO, Regional Center for Tropical Biology. Bogor, Indonesia, 1978)

9. D. H. Les, D. J. Crawford, E. Landolt, J. D. Gabel, R. T. Kimball, Syst. Bot., 27, 2 (2002)

10. E. M. A. Nafea, J. Mediterr. Ecol., 14, (2016)

11. L. Landesman, N. C. Parker, C. B. Fedler, M. Konikoff, Livest. Res. Rural Dev., 17, 6 (2005)

12. R. A. Leng, JH Stambolie, R Bell, Livest. Res. Rural Dev., 7, 1 (1995)

13. M. D. Ansal, A. Dhawan, V. I. Kaur, Livest. Res. Rural Dev., 22, 7 (2010)

14. T. Chrismadha, F. Sulawesty, A. Awalina, Y. Mardiati, E. Mulyana, M. R. Widoretno, Proceeding of International Conference of Aquaculture Indonesia ICAI, (2014)

15. R. Chakrabarti, W. D. Clark, J. G. Sharma, R. K. Goswami, A. K. Shrivastav, D. R. Tocher, Front. Chem. (2018)

16. P. Skillicorn, W. Spira, and W. Journey, Duckweed aquaculture: a new aquatic farming system for developing countries (The International Bank for Reconstruction and Development/THE WORLD BANK, Washington, D.C. 20433, U.S.A.,1993)

17. T. Chrismada E. Mulyana, LIMNOTEK Perair. Darat Trop. di Indonesia, 26, 1 (2019)

18. F. Amalia, K. Nirmala, E. Harris, T. Widiyanto, LIMNOTEK Perair. Darat Trop. di 
Indonesia, 21, 2 (2014)

19. A. P. Ilyas, K. Nirmala, E. Harris, T. Widiyanto, LIMNOTEK Perair. Darat Trop. di Indonesia, 21, 2 (2014)

20. F. D. A. Tavares, J. B. R. Rodrigues, D. M. Fracalossi, J. Esquivel, R. Roubach, Biotemas, 21, 3 (2008)

21. G. M. Srirangam, Int. J. Fish. Aquat. Stud., 4, 6 (2016)

22. E. Y1lmaz, I. Akyurt, G. Günal, Turkish J. Fish. Aquat. Sci., 4 (2004)

23. A. Tesfahun, Int. J. Fauna Biol. Stud., 5, 1 (2018)

24. L. E. C. Conceicao, Growth in early life stages of fishes: an explanatory model (Landbouwuniversiteit, Wageningen, 1997)

25. M. A. M. Machiels, Aquaculture, 64, 4 (1987)

26. M. A. M. Machiels, A. M. Henken, Aquaculture, 60, 1 (1987)

27. M. A. M. Machiels, A. A. Van Dam, Aquaculture, 60, 1 (1987)

28. M. Giammarini, M. Conti, S. Orcioni, System-Level Energy Estimation with Powersim (ICECS, 2011)

29. A. Mascellino, EETech Media, LLC. (2020). [Online]. Available: https://eepower.com/news/powersim-unveils-new-power-electronics-simulator/\#. [Accessed: 28-Apr-2021].

30. A. N. F. El Haqque, Pemodelan Dinamika Sistem untuk Menganalisis Pertumbuhan dan Hasil Hutan (Sekolah Ilmu dan Teknologi Hayati ITB, Bandung, 2020)

31. D. L. Trenggonowati, I. Safi'i, A. Umyati, J. Ind. Serv., 5, 2 (2020)

32. G. Ernst, J. Crit. Care, 20, 4 (2005)

33. S. Alam, K. Ahmad, J. Energy Res. Environ. Technol., 2, 2 (2015)

34. W. E. Ricker, Growth rates and models Fish Physiology Vol. VIII (Academic Press, Inc., 1979)

35. Y. Barlas, Syst. Dyn. Rev., 12, 3 (1996)

36. M. J. Musiba et al., African Crop Sci. J., 22, Issue Supplement s4 (2014)

37. T. Chrismadha, D. S. Said, Pengembangan alternatif budidaya perikanan jaring apung: Meningkatkan efisiensi produksi kolam perikanan darat dengan tumbuhan mata lele (Lemna perpusilla Torr.) (Laporan Teknis, Puslit Limnologi, 2019)

38. D. R. Hariyadi, A. Isnansetyo, I. Istiqomah, I. Hardaningsih, W. Wahyudi, S. S. Kim, Aquac. Indones., 19, 1 (2018)

39. T. A. Musefiu, Biomed. J. Sci. Tech. Res., 9, 3 (2018)

40. P. H. T. Soedibya, T. B. Pramono, E. Listiowati, E3S Web of Conferences. SCiFiMaS 2018, 47, 02002 (2018)

41. S. Amisah, M. A. Oteng, J. K. Ofori, J. Appl. Sci. Environ. Manag., 13, 1 (2009)

42. K. Marimuthu, R. Umah, S. Muralikrishnan, R. Xavier, S. Kathiresan, Emirates J. Food Agric., 23, 4 (2011) 